\section{Сара Мајсторовић}

Универзитет у Новом Саду

Филозофски факултет

Студент докторских студија

sara.majstorovic93@gmail.com
UDK 821.163.41.09-2 Pekić B. DOI: 10.19090/zjik.2019.179-193 оригинални научни рад

\title{
ЖАНРОВСКА ВАРИЈАТИВНОСТ ЧУДА У ЈАБНЕЛУ БОРИСЛАВА ПЕКИЋА: УНИВЕРЗАЛНОСТ И ТРАГИЧНОСТ ЧУДА
}

САЖЕТАК: У раду се анализира радио-драма Борислава Пекића Чисти и нечисти спрам њене прозне варијанте Чудо у Јабнелу, са циљем утврђивања естетских резултата таквог жанровског варирања. Увиђа се да кроз употребу драмског израза настају нова значења. Анализа се заснива на структуралистичком приступу тексту, као и на његовом сагледавању у контексту теорије модерне драме. Утврђује се да је, упркос површинској сличности између варијанти, реч ипак о два одвојена дела, са различитим тематским тежиштем и идејном подлогом. Прозна варијанта је превасходно дијалог са библијским предлошком, док кроз драмски текст писац оживљава насилно искуство неуклопљености у затвореној заједници. Имплементацијом елемената комичног и трагичног, Пекић потцртава основну идеју о трагичности сваког наметнутог добра. Постоји нада де ће овај рад допринети бољем разумевању својстава и места драме у опусу Борислава Пекића.

Кључне речи: жанровска варијанта, радио-драма, приповетка, Чудо у Јабнелу, Борислав Пекић

Борислав Пекић је изјавио да у своје драме сврстава „све оно што, из било каквих разлога, од романескне теме, у роман није могло стати, а, пре или касније морало се рећи“ (Pekić 2007: 120). И ако се у истом есеју о позоришту потражи разлог зашто се морало рећи, долази се до разлога опредељења за драмску форму који „лежао је психолошки у снажној потреби за неком акцијом“ (Pekić 2007: 118). Овај рад има за циљ да утврди технике одабира грађе као и естетске резултате драмског израза на примеру драмске варијанте приповетке Чудо у Јабнелу из збирке приповедака Време чуда. Већ при првом читању, показује се да ограничења рода нису једино што условљава садржину Пекићеве драме Чисти и нечисти или Чудо у Јабнелу. 
Полазећи од тога, аутор остварује своју уметничку „акцију“ и другим средствима. Између прозне и драмске варијанте настаје разлика у тематском тежишту, естетским својствима али и идејној подлози, што је могуће видети на примерима дијалога, другачије карактеризације ликова, веће емоционалности текста. Смештајући радио-драму Чисти и нечисти или Чудо у Јабнелу у књижевнотеоријски контекст жанра, али и у теоријске оквире модерне драме, постаје јасно да је упркос површинским сличностима овде ипак реч о два одвојена, независна, и различита дела. Кроз структуралистичку анализу истражује се и улога комичних и трагичних елемената који у својим формалносадржинским аспектима учвршћују идејну подлогу драме и потцртавају њену разлику у односу на прозну варијанту.

Збирка приповедака Време чуда објављена је 1965. године. Драмска варијанта једне од приповедака, Чудо у Јабнелу, под насловом Чисти и нечисти или Чудо у Јабнелу, објављена је постхумно, тек 2006. године. Извођена је као радио-драма пре тога, али након објављивања прозног предлошка. Истина је да сагледавање Пекићевог драмског опуса као средства „за промотивну демонстрацију и додатну елаборацију тема, мотива и поетичких стратегија већ развијаних унутар његовог... прозног опуса“ (Јованов 2006: 347) ствара предуслов да његове драме не буду довољно истражене, али овакво пишчево самоодређење може послужити и као својеврсна смерница управо за тумачење његовог драмског дела. Полазећи од наслова радио-драме која је тема овог рада, уочава се да он указује на универзалну проблематику „чистих“ и „нечистих,“ док наслов приповетке смешта ово чудо у оквир Времена чуда, као један његов саставни део. Чисти $и$ нечисти тематизује искуство болести у контексту друштва, док је прозна варијанта овог дела саставни део збирке приповедака са другачијим тематским тежиштем.

По Теорији књижевности Драгише Живковића, у драмском делу важно место заузимају елементи као што су: приказ сукоба двају супротних ставова, динамичан ток згуснуте и изоловане радње која се одвија у садашњости, постојање слепе друштвене и природне силе, приказ појединачне судбине и прелаз једног психичког стања у свесну одлуку воље и у активно испуњавање те одлуке. Јасно је да су из одређених видова експерименталног позоришта неки од ових 180 
елемената искључени, најчешће намерно. У случају драме Чисти $u$ нечисти, изостају формални експерименти и утицај анти-драме услед „самосвојне логике развоја пишчеве глобалне поетике, која у хронолошком смислу углавном одудара од динамике смењивања 'стилских формација' модерне српске и ех-уи драматургије...“ (Јованов 2006: 347). Остајући доследан самосвојној поетици, Пекић задржава традиционалне функције дијалога и драмску радњу у њеном постепеном развијању. Тако постаје јасно да су одређене разлике између драмске и прозне варијанте Чуда у Јабнелу условљене разликом њиховог књижевног рода. Могућност постојања других разлика и њихове естетске импликације, предмет су даље анализе у овом раду.

Апсурд којим је прожета анти-драма Пекић приказује више „у камијевском смислу, као немогућност остваривања слободне воље индивидуе и као вид бесмислености и ништавила људске егзистенције“ (Ковачевић 2012: 23). Он инкорпорира у драмску варијанту Чуда у Јабнелу и елементе комичног и трагичног, мада тренутак и интензитет појављивања ових елемената такође служи као илустрација његових идеја. Аутор „помоћу хумора, ироније, цинизма преиспитује и поиграва се са колективним привидним истинама и представама, релативизује их, сагледава са наличја, указујући на њихову парадоксалност, апсурдност, бесмисао“ (Ковачевић 2012: 25).

Даље, формално гледано, као што је Милена Илишевић у својој жанровској анализи Пекићевих драма приметила, драма Чисти $u$ нечисти одређена је као „прва библијска бајка“, чиме „Пекић истовремено проблематизује два појма: жанр драме (радио) и жанр бајке... Овако конципиран поднаслов... нуди један од могућих кључева за тумачење хришћанске свете књиге“ (Илишевић 2011: 81). Назив „бајка““ имплицира повест о нестварним догађајима са љубавним заплетом срећног краја. Овакав назив дакле наглашава иреалност збивања у Јабнелу, а као травестија бајке, ова љубавна прича има несрећан крај. У драми се казује да „Еглина болест беше, дакле, једно чудо“ (Pekić 2006b: 317) што, с обзиром да је болест негативно семантизована, може да значи чудо у смислу необичног или скандалозног догађаја који ће касније постати урбана легенда, а не нужно у смислу узвишеног догађаја са пореклом у божанском; израз „чудо“ овде се може разумети и иронично. Ово учвршћује нашу идеју 
да је болест више тема драме него чудо излечења, које се у приповеци одређује као тематско тежиште.

Фабула Чуда у Јабнелу, и приповетке и драме, приказује исцељење губавке Егле од њене болести посредством чуда Исуса Христа, и њен живот после тог чуда. Исцељење се одвија у долини између насеља губавих и насеља здравих, где Исус затиче Еглу. Ипак, овај месијин поступак се не показује као једнообразно добар. Сумњичава због њеног новог здравља, заједница здравих је не прихвата назад, а увидевши да није више губава, одбацују је и губавци, којима се Егла окреће када види да не може да се врати у своје старо окружење. У приповеци се казује да није било „записано“ да ово чудо треба да се деси, за разлику од осталих. Међутим, постаје јасно да то није разлог његове крајње „неуспелости“, када се сагледа спрам осталих чуда у збирци приповедака. У контексту осталих чуда у Времену чуда, чудотворство, по себи, појављује се као проблем, као наметање здравља и излечења тамо где оно није експлицитно тражено, и Пекић сугерише да су, самим тим, последице по живот излечених далеко од очекиваних. С обзиром на изостанак оваквог контекста у драми, њено тематско тежиште се помера ка уопштеној дебати о здрављу, болести и стигми у људској заједници одређеног историјског контекста, али и шире, што доприноси релевантности ове драме као књижевног дела.

Као илустрација разлике у тематици прозе и драме, не може промаћи чињеница да мало мање од половине драме чине Еглине расправе с мужем, Јеробоамом, о њеној болести. Након предочавања свог здравственог стања мужу, њих двоје полемишу о важности да се то држи у тајности, о неповољном одразу које то може имати на његово унапређење, о уверењу да је то сигурно Божија казна за неки Еглин грех и о могућности да појава пришта није казна већ Божији знак да ће Егла постати пророчица. Одлучују да се моле за Еглин опоравак, што чине данима узастопце без резултата. Јеробоам чак предлаже да се моле другим боговима, што Егла одбија, изјављујући да мрзи све богове; уследи одлука о њиховом скором растанку. Егла проводи скоро половину драме на ничијој земљи између болести и здравља, у слутњи о природи своје болести и у нади да ће оздравити, све до одсудног тренутка када се пресели у Нови Јабнел, насеље 182 
губавих. С друге стране, процес њеног одласка у прозној варијанти чини мање од једне петине текста. Расправа са Јеробоамом о болести је само увод у причу, а Еглин боравак на међи између чистих и нечистих означен је као „прави почетак приче“, јер ће се на том месту десити чудо које је тематска окосница прозне варијанте.

Може се тврдити да повлашћен положај дијалога у драмској варијанти произилази из њене врсте, да радио-драма обавезује на дијалог јер не постоје друге, невербалне, сценске могућности израза (сценографија, мимика, покрет, светла). Ипак, Пекић овде даје првенство дијалогу и над класичним развојем радње. У модерној драми постоји тенденција ка минимизирању дијалога; у њој се често „унутрашња противречност... састоји... у динамичком прелажењу субјекта у објекат и објекта у субјекат“ (Сонди 2008: 95). У овој Пекићевој драми актери дијалога се јасно држе својих различитих становишта и њихова динамична интеракција покреће радњу. Могло би се тврдити, посебно у контексту Пекићеве прозе, да је писац, радије него да се бави формалним експериментима у драмском жанру, желео овде да, првенствено посредством дијалога, артикулише једну драму идеја. Након иницијалног дијалога о природи Еглине болести, могућност дијалога се смањује како се обе заједнице, и здрава и болесна, затварају према Егли. Пред крај драме, у сцени где Егла моли Јеробоама да јој отвори врата, њихов дијалог се монологизује; Егла „заборавља свог партнера и говори ‘за себе' одајући се успоменама“ (Мукаржовски 1981: 288). Она рецитује „Песму над песмама“, коју јој је Јеробоам често рецитовао у љубавном заносу док је живела са њим у Старом Јабнелу. То чини тихо, само за себе, током неуспешног дијалога; у контексту њиховог потпуног неразумевања, она се препушта сећањима.

За разлику од разговора, сва дешавања у комаду су сабијена у другу половину драме и смењују се брзо и динамично. У складу с тим, показује се да ова драма има необичну, продужену експозицију, схваћену као разговор „двају или више лица на почетку развијања саме радње“ (Живковић 1994: 141). У прологу смо обавештени о појави Еглине болести, али у експозицији она то саопштава Јеробоаму и они дискутују о природи и значењу те појаве и њиховим даљим могућностима. До заплета долази тек у другој половини текста, у 
тренутку када Егла одлучи да напусти Стари Јабнел. У прозној варијанти дијалог има секундарно место у односу на приповест свезнајућег приповедача у којој су неке деонице дијалога и препричане. Приповедач саопштава развој догађаја, филозофира на споредне теме, обликује ликове унутрашњом карактеризацијом и доживљеним говором, а дијалог служи само као покретач његових разматрања.

Ако се драмски текст посматра као драма Еглине болести, онда кулминацију представља сцена њеног повратка код Јеробоама, који се плаши да је прими назад. У том тренутку, Егла истовремено пребива у свету здравих и болесних, између чистих и нечистих; она постаје симбол њихове међусобне нетрпељивости, и тако бива протерана и од једних и од других, што представља расплет драме. Више него поједини ликови, радњу усмерава став групе, која и јесте на мети Пекићеве критике. У драми Јеробоам страхује да ће га заједница изопштити ако Еглу прими назад, док се у прози само боји да ће га она заразити губом. Драматичност Еглине неуклопљености поткрепљују њени променљиви ставови према губавости, која јој је одвратна док живи у свету здравих, а мање одвратна кад тај свет напусти.

У прозном предлошку, уместо на сукобу два света, тематско тежиште је на причи о Еглином излечењу. На почетку приповести Егла је већ у Новом Јабнелу, и кроз ретроспективно приповедање свезнајућег приповедача сазнајемо како је ту доспела. Приповест се наставља у „садашњости“, када Исус Христос затиче Еглу на међи између два града, опхрвану носталгијом за бившим мужем и пређашњим животом. Током разговора са Исусом, приповедач предочава сплет сложених мотива због којих Егла на крају пристане да буде исцељена, иако је неповерљива према младићевим чудотворним моћима:

Осећајући да му је стало до сарадње која њу не би ништа коштала, она помисли да благонаклоно попустљиво опхођење с једним несрећником, кога је Адонај казнио горе него њу, може на одговарајућем месту бити регистровано и примљено као рата отплате за давно почињен грех... (Pekić 2006а: 47). 
Проза изискује директно мотивисање радње, у овом случају посредством „формалне сродности апокрифног типа, јер скрива, лажно представља право значење текста“ (Пијановић 1991 : 29). Иако, или баш зато што, је текст „у спору са правоверном хришћанском догмом“ (Пијановић 1991 : 29) он задржава фабулативни костур библијског текста. Драма дозвољава да се догађаји одвијају услед сплета околности (Еглино оздрављење резултат је случајног сусрета), посебно када се одвијају ван сцене. У прозној варијанти је приказана и Еглина усхићеност новопронађеним здрављем и њена захвалност Богу, након чега следи контрастно отрежњење непријатељски настројене стварности.

Исусова појава у прозном тексту појачава веродостојност Еглиног излечења. Њихов сусрет у драми је само препричан, и сам слушалац се може двоумити да ли је Егла заиста излечена или је реч о њеној уобразиљи, што појачава тензију кулминације и неизвесност њеног међуположаја. Одсуство лика Исуса Христа из драме условило је такође уклањање Христовог имена из Јеробоамовог прогласа који он вежба наглас током оне вечери када Егла покуша да му се врати. Тако се Исусов лик и његова чудотворства представљају сасвим посредно, чиме се постиже утисак веће универзалности приче; Исус је свака особа (Егла га зове „младим богом“) која је у некој заједници постала позната по исцелитељским моћима које јој се приписују. Појављивање осталих ликова се подудара у прозном и драмском извору.

У драми, Егла је окарактерисана као лепа, чулна жена, жељна љубави и пуна живота, али и пуна пркоса према Богу који ју је разболео без њене кривице: „није моје него Адонајово да брине о мом преступу, кад га је већ овако сурово, одурно, зверски обележио“ (Pekić 2006b: 327). У прози њен гнев је блажи а њена карактеризација усложњена интроспективним описом:

Али у свом чедном срцу Егла је зебла. И била усхићена тиме. Очајање, најпостојанији остатак њених старојабнелских успомена, снабдевало је њен занос све новим и упечатљивијим мученичким сликама, а занос је са своје стране подбадао патњу да производи још неподношљивије сцене... (Pekić 2006a: 29). 
У драми је појачан контраст између њене мржње према немилосрдном Богу и љубави и наде када је у питању Божији син који ју је излечио. На крају драме прогнану Еглу испуњава очајничка нада: „Овде сам питана верујем ли... Овде сам рекла: верујем... Овде ћу чекати... Можда ће млади Бог још једном овуда проћи...“ (Pekić 2006b: 346). Та нада протагонисткиње уклапа се у шири контекст Пекићеве драматургије као израз „немоћи јунака да опстане у тоталитарном систему који нарушава сваки вид индивидуалности и неконформизма“ (Ковачевић 2012: 27). У прози Егла испољава више огорчења Исусовим поступком: „одмазда за пркос (је) пала на моју главу. Сигурно не беше никаквог договора између Оца и Сина.“ (Pekić 2006а: 78). Такође, за разлику од драме, када ју је Исус питао да ли верује у чудо, Егла је одговорила одрично. Тако постаје јасна разлика између прозе која проблематизује веру и наметнуто, присилно, добро од стране спољне инстанце, и драме која тематизује односе унутар заједнице.

Могу се приметити извесне разлике и у особинама Еглиног мужа Јеробоама када је у питању љубомора или одважност. У односу на прозу, Јеробоам је у драми љубоморнији али и потресенији неповољном ситуацијом: „(Виче) Егла!... Егла!... Егла...! (Глас му се сломи, зајеца.)“ (Pekić 2006b: 330). Емотивност ликова доприноси повећаној драмској експресивности текста, који тежи да изазове емотивну реакцију и код слушалаца. Веран традиционалној функцији дијалога у драми, функцији приказивања сукобљених мишљења и осећања, Пекић уноси емотивност и острашћеност и у Еглин и Јеробоамов дијалог:

E: То је то, Јеробоаме. То је губа.

J: (ужаснуто) Не!

$\mathbf{E}:$ Да, разболела се сад и кућа.

$\mathbf{J : ~ М о л и м о ~ о н д а , ~ Е г л а , ~ м о л и м о , ~ ш т а ~ ч е к а м о ! ~}$

$\mathbf{E}:$ (хладно) Смири се, сабери, престани кукати и седи тамо... Имам нешто да ти кажем. (Помало свечано и извештачено) Јеробоаме, мужу мој и Господару!...

J: (Вапи) Јао мене кукавног!“ (Pekić 2006b: 326). 
У прози су емоције представљене као одмереније и мотивација ликова као сложенија и мање непосредна:

'Јеробоаме, сутра ме води слузи твог бога Исмају, да се сврши.' Јеробоам, коме се дремало, попусти и обрече да ће је сутра свештеник Исмај прегледати... Истини за вољу, никаква љубав није могла сачувати Јеробоамова колена од жуљева што су их наталожиле... покајничке молитве, и никаква брачна оданост није могла толико да га заћори да... не предвиди изглед своје жене, за месец, за годину (Pekić 2006a: 35).

Појачан емотивни набој у драмској варијанти замењује разгранату мотивисаност поступака ликова у прозном предлошку. Еглин однос са својим новим, губавим мужем Уријом опширно је мотивисан у прози: „Здружио их је равноправан однос према судији Адонају [...] здружило их је неприхватање греха који им је био приписиван [...] изазвана осећањем неоправдане напуштености, плот их је здружила у привремен савез“ (Pekić 2006а: 38). У драми су емоције употребљене као средство контрастирања; без објашњења са сцене тужног љубавног растанка са Јеробоамом прелази се на љубавну сцену у Уријином кревету, која је испуњена пожудом. Еглин и Уријин однос је објашњен тек касније кроз дијалог. Поред ефекта драмског контраста, опште појачан емотивни набој у драми у поређењу с прозним предлошком чини лакшим саосећање са ликовима и уживљавање у њихову ситуацију, која се чини уверљивијом. Док је прозна варијанта приповест о догађају у прошлости, драма нуди доживљај текста у садашњости.

Једна од најважнијих одлика Еглиног лика, њена несврстаност, непотпуно припадање и свету здравих и свету болесних, испољава се у физичком боравку у међупростору између два града, али и у мотиву двојнице, који се појављује у исказима њених мужева, бившег и садашњег. Што се саме Егле тиче, она је одана двема странама: „, [...] ја још увек волим и Јеробоама, општинског викача из Старог Јабнела [...] истина не би била потпуна, кад не би била и обрнута, па садржала и моју страсну наклоност према теби, Уријо Бен Мијаму“ (Pekić 2006b: 332). Урија то разуме на следећи начин: „Све је то зато што ти, нажалост, ниси још сасвим наша, сасвим губава“ (Pekić 2006b: 332). Егла такође и даље делимично припада свету здравих тиме што јој се 
Јеробоам обраћа у својим царским објавама. Несврстаност се пооштрава до двојства након Еглиног исцељења, што кулминира у Јеробоамовој реплици: „Закључао сам врата не пред својом љубљеном Еглом, већ пред њеном грешном и губавом двојницом, која се, пркосећи Закону враћа са места испаштања да ме упропасти“ (Pekić 2006b: 336). Урија такође тврди да је жена која покушава да му се врати можда једном била његова Егла, али да, здрава, сада засигурно то није.

Ове заједнице идентификују особе као здраве или болесне по двоструком критеријуму, унутрашњем (духовном, менталном) и спољашњем (физичком). Заједница здравих презире спољашње знаке здравља јер не могу да посведоче о „духовном“ излечењу, док у губаву заједницу може бити сврстана само особа са спољашњим знацима обољења. По таквом поимању, Еглин спољашњи и унутрашњи идентитет се не поклапају; она поставља питање о могућности таквог непоклапања и код других, па каже Урији: „, [...] ни ти ниси баш сасвим губав, као што ни они тамо преко, можда, нису баш без и мало губе, као што замишљају“ (Pekić 2006b: 333). Они који су споља здрави можда размишљају на „болестан“ начин, а они који су споља болесни можда размишљају на здрав начин. У симболичком читању, раздвајање на апсолутно здраве и апсолутно болесне приказује се као апсурдно, и проблематизује се постојање ауторитета који би могао да изврши ту поделу. Као многа Пекићева дела, и ова прича, у оба своја облика иако на различит начин, показује се као критика искључивог мишљења, које управо производи оно против чега се бори - м неуклопљеност. Пекићево поимање истине увек оставља простор за инхерентне противречности.

Док су у драми пластично контрастиране две Еглине љубави, у прози су, с тим у вези, елабориране околности под којима је Еглу затекао спаситељ и над њом извршио чудо. С обзиром на то да ју је нашао како опхрвана носталгијом лежи на међи између два града, Еглина патња се показује као покретач одсудне радње у приповеци. У драми се њено исцељење приказује као случајан догађај а њен однос према губавости као мање испуњен очајањем. Иако се драма структурира око дијалога, саму њену радњу у овом случају покрећу догађаји који су ван контроле ликова: појављивање Еглине болести и 188 
случајан сусрет са Христом. Важне тачке радње (одлазак код свештеника Исмаја, сам чин исцељења) изостављене су у драми, а сцена растанка од Јеробоама директно претходи сцени љубавног уживања са Уријом. У драмској варијанти, у Еглином лику се дешава расцеп, и заокрет ка „губавом“ мишљењу, што се не дешава у прозној варијанти. Тако она признаје да се у ствари моли Богу да учини и Јеробоама губавог јер „зар има лепшег стања на свету од губавог?“ (Pekić 2006b: 334). У драми се тако конкретизује оно што је у прози симболично приказано. Еглино прећутно прихватање живота у губавој заједници огледа се у њеном новом браку и функционисању у новој свакодневици. Ипак, у прози се не дешава инверзија у пожељности болести спрам здравља; Егла машта о здравом Јеробоаму. У драми њено физичко стање производи преокрет у њеном начину размишљања.

Промена у Еглином поимању болести чини болест, парадоксално, видљивијом за слушаоца радио-драме. Поред функције контраста у односу на претходне дијалоге, показује се да Еглино прихватање свог новог „губавог живота“ има још једну сврху. Као неко ко је отишао од једног начина живота и са спремношћу прихватио други, Егла оличава ведар, помирљив дух комичног поимања живота, те вечите силе која прихвата и контекстуализује људске несреће и тако их, заправо, савладавава: „Не постоји трајан пораз и трајан људски тријумф, осим у трагедији, јер природа мора да траје, ако траје живот, а свет који поставља све запреке такође пружа и животне сласти. У комедији, стога постоји опште умањивање значаја људске борбе“ (Лангер 1981: 400). И заиста, Еглини и Јеробоамови разговори, поред снажних емоција, прожети су и комиком:

$\mathbf{E}:$ Болесна сам, Јеробоаме, коњу, чујеш ли?

$\mathbf{J}:$ Јеси ли нешто рекла, душо?

E: Рекла сам: Јеробоаме, коњу, болесна сам!

J: У реду. То знамо. Од тога у калкулацијама и полазим. То је само прелазно стање до видовитости (Pekić 2006b: 322).

Или:

E: Можда сам нешто згрешила?

$\mathbf{J}$ : Па јеси ли, јеси ли? 
$\mathbf{E}:$ А откуд знам? Чак и да јесам, не бих се сетила. Од толиког ринтања по кући, не знам ни где ми је глава, а некмоли грехови... J: Кад смо већ код тога, требаће ми за сутра чиста кошуља, душо“ (Pekić 2006b: 322).

Прозна варијанта оставља мање простора за комично; приповест је у овом случају озбиљнија, психолошки продубљена, чак са лирским изливима. Еглино прихватање новог живота представљено је као избор наметнут силом прилика, избор живота уместо смрти, али без страственог прихватања новог стања као што се то дешава у драми. У прози не долази до субјективног искривљења лепог и ружног нити до емотивне уцене болешћу. Егла је „најсексипилнија удавача Новог Јабнела“" (Pekić 2006a: 38) баш зато што је тек од скоро начета болешћу. Њој се допада лежерни израз Уријиног лица, он је леп, али само „на начин прикладан за губавца“ (Pekić 2006a: 38).

Постаје јасно да чудо, парадоксално, уноси у ову драму трагично осећање света које преобраћа Еглину трезвеност, прилагодљивост и истрајност у томе да има какав-такав живот у личну трагедију сукоба једног несврстаног идентитета са слепом силом тоталитарног колектива. Чудо тежи за апсолутом Еглиног здравог идентитета, оно одбија животни ток који је одредио да ће се Егла разболети и потврђује и изоштрава њену неуклопљеност, која тако постаје извор трагичности. Чудо даје тежину и озбиљност њеној судбини. Бирајући изгнанство и изопштавање, та судбина постаје трагична. Пекић је, не само посредством тематике и дијалога, него и посредством драмског поступка, везујући осећање трагичног за Христово чудотворство, пренео своју поруку о погубности наметнутног (и натприродног) доброчинства у свету који функционише по крутим друштвеним законима.

Већи универзализам драме у односу на прозну варијанту испољен је и у почетном дијалогу Егле и Јеробоама. Истина је да Пекић у својој есејистици позива на опрезност када приписујемо особине својих савременика књижевним ликовима који потичу из другог историјског контекста, али чињеница је такође да Пекић сатиричним тоном своје драме коментарише и садашњост. Обраћа се 
човековој потреби да свакој појави да смисао и значење, по могућству значење које би искључивало кривицу а доказивало личну исправност. Мета критике у дијалогу драме Чисти и нечисти су и међуљудски односи који захтевају да се друштвено контроверзна појава држи у тајности; у контексту Јудеје пре две хиљаде година то је болест, у каснијим временима то је свакако нешто друго што би се сматрало „срамотом.““

Писац подвргава критици и човекову потребу да значајне догађаје смешта у религијски контекст. Егла и Јеробоам сматрају да њихови животи зависе од Бога као метафизичког ауторитета који може да их казни или награди. Њихово јововско трагање за разлогом и објашњењем се на крају исцрпљује у банално схваћеној молитви, богохуљењу и Еглином одбијању да поверује да је судбоносно згрешила. Јеробоам њен самосталан, критички став сматра скандалозним, и спрам његовог богобојажљивог става, који је „здрав,“ Еглин се приказује као „болестан.“ Она ће наићи на разумевање за такав став тек код Урије, свог губавог мужа. И Урија и Јеробоам тако илуструју неапсолутност и контекстуалност романтичне љубави.

Као у параболи о Великом Инквизитору, Исусова чуда су у обе варијанте овог дела схваћена као непотребна и чак штетна за смерне и побожне људе. Услед своје одбачености од друштва, Егла доживљава да постоји двосмислена повезаност између ње и спаситеља: „као што ти не знаш кад си Бог а кад човек, ни ја не знам кад сам у срцу Јеробоамова а кад Уријина...“ (Pekić 2006а: 48). Такав паралелизам изостаје у драми, мада се њихова повезаност у њој очитује у Еглиној снажној вери.

Књижевнотеоријском анализом у структуралистичком кључу, утврђује се да се разлике између прозне и драмске варијанте Чуда у Јабнелу не исцрпљују у разилажењима књижевних родова, већ су присутне и на тематском и идејном плану. Драма Чисти и нечисти богатија је од свог прозног предлошка у дијалогу, емотивном набоју и живошћу ликова. Дело нема драмску форму ради самог драмског израза и експериментисања са њим, већ је пластичан приказ цинизма и предрасуда једне затворене заједнице, кроз који Пекић 
проблематизује поимање болести, здравља и припадности колективу. У симболичком читању подела на апсолутно чисте и апсолутно нечисте показује се као фикција која може имати насилне последице. Опадање разумевања између ликова илустровано је смањивањем способности за дијалог. Кроз драмски израз Пекић настоји да изазове сажаљење за сваку жртву изопштавања. Драмски текст тако испољава већи степен универзалности од прозне варијанте. Док комични елементи ове драме илуструју снагу, помирљивост и ведрину протагонисткиње, трагично осећање света појављује се након што је над њом извршено чудо, јер такво наметнуто добро осуђује је на изгнанство. Жанровским варирањем текстова, Борислав Пекић их је обогатио комплементарним нијансама у значењу, разноврсним естетским квалитетима и различитим перспективама на једну исту проблематику, стварајући тако два независна дела.

\section{ЛИТЕРАТУРА}

Живковић, Драгиша. 1994. Теорија књижевности са теоријом писмености. Београд: Завод за уџбенике и наставна средства.

Илишевић, Милена. 2011. Жанровска преплитаға у савременој српској драми: други чин расправе у два чина. Београд: Институт за књижевност и уметност.

Jovanov, Svetislav. 2006. „Gore je dole, ili maska svih maski“. Roboti $i$ sablasti - izbor iz neobjavljenih drama. Novi Sad: Solaris. 347354.

Ковачевић, Јелена. 2012. „Проблем идентитета јунака у драмама Борислава Пекића“. Свеске 105/106 (23): 22-28, 26-35.

Лангер, Сузан. 1981. „Велике драмске форме: комички ритам“, у: Миочиновић, М. ур. 1981. Модерна теорија драме. Београд: Нолит.

Мукаржовски, Јан. 1981. „Две студије о дијалогу“, у: Миочиновић, М. ур. 1981. Модерна теорија драме. Београд: Нолит.

Pekić, Borislav. 2006a. Vreme čuda. Novi Sad: Solaris.

Pekić, Borislav. 2006b. Roboti i sablasti - izbor iz neobjavljenih drama. Novi Sad: Solaris.

Pekić, Borislav. 2007. Izabrani eseji. Novi Sad: Solaris. 
Пијановић, Петар. 1991. Поетика романа Борислава Пекића. Београд: Просвета.

Сонди, Петер. 2008. Студије о драми. Нови Сад: Орфеус.

Sara Majstorović

GENRE VARIATION OF THE MIRACLE IN YABNEL BY BORISLAV PEKIĆ: THE UNIVERSAL AND TRAGIC IN A MIRACLE

\section{Summary}

The paper analyzes the radio-play The Clean and the Unclean by Borislav Pekić in relation to its prose variant, The Miracle in Yabnel, with the aim of determining the aesthetic results of such variation. It is observed that through dramatic expression new meaning is generated. Analysis is based on a structuralist approach to the text, as well as on its observation in the context of literary theory concerning the modern drama. It is determined that, despite surface similarity, these are two separate texts, with a different theme and background idea. The prose variant is mainly a dialogue with biblical subtext, whilst through the dramatic text the author demonstrates the violent experience of not belonging, in a closed community. Through the implementation of comic and tragic elements, Borislav Pekić underlines the basic idea of the tragedy of every imposed good. This paper aims to contribute to the better understanding of the characteristics and role of the drama in the work of Borislav Pekić.

Key words: genre variation, radio play, short story, The Miracle in Yabnel, Borislav Pekić 